\title{
A gyógyfürdőkre és balneo kozmetikumokra irányuló vásárlói és fogyasztói magatartás kvalitatív vizsgálata a Közép-magyarországi régióban saját modell fejlesztésen keresztül \\ Qualitative study of customer and consumer behaviour towards spas and balneo cosmetics in the Central Hungarian region through own model development
}

\author{
Amberg N. ${ }^{1}$ \\ Magyar Agrár- és Élettudomány Egyetem, Gazdaság- és Regionális Tudományok Doktori Iskola, \\ nora.amberg@gmail.com
}

Absztrakt

A tanulmány címében megjelölt téma bemutatásának kiinduló pontja a közép-magyarországi (elsősorban a Budapest Gyógyfürdöi és Hévizei Zrt-hez ${ }^{2}$ tartozó) gyógyfürdök igénybevételére és a balneo kozmetikumok vásárlására és fogyasztására (különös tekintettel a Budapest Spas termékcsaládra, amely a BGYH Zrt. balneo kozmetikumcsaládja) ható tényezök közötti kapcsolatrendszert leiró - irodalmi és szekunder források alapján felépitett - elméleti modell ismertetése. Az elméleti koncepción keresztül érintett téma gyakorlati jelentöségét elsösorban a természetességhez, a témát tekintve a gyógyvizhez és a gyógyviz összetevőkből készült kozmetikumok vásárlásához és használatához történő visszatérés jelenti.

Az elméleti modell ismertetését követően az a kutatási modell-koncepció kerül ismertetésre, amelynek tényezöi a kvalitatív kutatási eredmények által új determinánsokkal lettek kiegészitve. A kutatási modell-koncepció kétfázisú kvalitatív adatfelvétel eredményeinek az értelmezésével került kialakitásra. Az adatfelvételekhez kapcsolódó célkitüzések (és eredmények) a következök voltak. (1) Online tartalom megfigyelés $(n=50)$ segitségével a balneo kozmetikumok vásárlásának és fogyasztásának föbb tényezöi lettek beazonositva. (2) Egyéni kutatási interjúk $(n=20)$ segitségével az elméleti modell érvényessége lett vizsgálva, illetve a gyógyfürdök igénybevételének és a balneo kozmetikumok vásárlásának és fogyasztásának föbb változói lettek feltárva, kiemelve a tudatosan eltöltött szabadidöt, az egészségtudatosságot és a rekreációt elötérbe helyezö vásárlói csoportositás irányok beazonositását. Jelen publikáció a modellfejlesztés és a legfontosabb kvalitativ kutatási eredmények bemutatását helyezi a fókuszba.

Kulcsszavak: gyógyfürdők, balneo kozmetikumok, vásárlás, fogyasztás, rekreáció

Abstract

The starting point for the presentation of the topic indicated in the title of the study is the use of spas in Central Hungary (mainly belonging to Budapest Spas cPlc.) and the purchase and consumption of balneo cosmetics (especially the Budapest Spas product family, which is Budapest Spas cPlc.'s balneo cosmetics family). Description of a theoretical model describing the system of relations between the

\footnotetext{
${ }^{1}$ https://orcid.org /0000-0003-3583-9132

2 BGYH Zrt.
} 
influencing factors - built on the basis of literature and secondary sources. The practical significance of the topic covered through the theoretical concept is primarily the return to naturalness, in terms of the topic, to medicinal water and the purchase and use of cosmetics made from medicinal water ingredients. Following the presentation of the theoretical model, the research model concept is described, the factors of which have been supplemented with new determinants by the qualitative research results. The research model concept was developed by interpreting the results of two-phase qualitative data collection. The objectives (and outcomes) associated with the surveys were as follows. (1) With the help of online content monitoring $(n=50)$ the main factors of buying and consuming balneo cosmetics were identified. (2) With the help of individual research interviews $(n=20)$ the validity of the theoretical model was examined and the use of balneo, the main variables of the purchase and consumption of cosmetics were explored, highlighting the identification of consumer grouping directions that focus on consciously spent leisure time, health awareness and recreation. This publication focuses on the presentation of model development and key qualitative research findings.

Keywords: spas, balneo cosmetics, purchasing, consumption, recreation

JEL Kód: M31

\section{Bevezetés}

A gyógyvizek egyre inkább előtérbe kerülnek a fizikum rekreációjában, regenerációjában, illetve a bör egészségének és szépségének a helyreállításában (Bender, 2008, Márk, n.a., Balneoportál, 2018, Shutt, 2002), ezért a gyógyvíz egészségre és szépségre gyakorolt hatása a kapcsolódási pont a gyógyvíz alapú szolgáltatások igénybevétele és a spa kozmetikumok használata, illetve ezek együttes vizsgálata között, mindezek mellett a spa kozmetikumokkal végzett olyan terápiás lehetőségek is további kapcsolódási pontként szolgálnak, mint a gyógymasszázs vagy a gyógykozmetika (Fási, Koronczai, 1996).

A hazai gyógyfürdők közül a BGYH Zrt.-hez tartozó gyógyfürdők fürdőtevékenységei, saját kozmetikai termékcsaládjuk, a Budapest Spas lettek részletesebben vizsgálat alá vonva.

A teljes hazai gyógyvizekkel és a különböző balneo kozmetikumokkal kapcsolatos kutatás módszertanát tekintve irodalom feldolgozás, szekunder, illetve primer (kvalitatív és kvantitatív) kutatások, amelyek lépései a következőkben foglalhatóak össze:

1. Elméleti modell megalkotása az irodalom feldolgozása segítségével, illetve az internet alapú spa kozmetikumok fogyasztásával kapcsolatos vélemények elemzésével és a budapesti gyógyfürdők forgalmi statisztikái alapján.

2. A módosított, pontosított elméleti modell megalkotása a kvalitatív kutatási eredmények alapján, továbbá a gyógyvíz alapú rekreatív szolgáltatások és kozmetikai termékek fogyasztói, vásárlói preferenciájával, szépségápolásra gyakorolt hatásával kapcsolatban.

3. A gyógyvizek és a gyógyvíz alapú kozmetikumokkal kapcsolatos fogyasztói, vásárlói magatartás tényezőinek feltárása (kvalitatív kutatás).

4. A tényezők közötti kapcsolatrendszer és az összefüggések leírása, értékelése kvantitatív kutatás segítségével.

5. Végleges kutatási modell kialakítása a kvantitatív kutatási eredmények alapján.

A vásárlás és a fogyasztás egymással összefüggö fogalmak a tanulmányban, mivel a gyógyvizek igénybevétele elsösorban a gyógyfürdö belépöjegyek megvásárlásával, illetve a balneo kozmetikumok is megvásárlás útján érhetőek el általában a fogyasztók számára, kivéve azokat az eseteket, amikor a fogyasztó ajándékba kapja ezeket a fürdöjegyeket/kozmetikumokat, azaz nem szükséges a használatukhoz azokat megvásárolnia, vagy, amikor ajándékba adja öket, mivel nem saját maga, hanem más fogyasztó fogja azokat igénybevenni/használni.

Korábbi publikációk tartalmazzák az 1., illetve a 4-5. pont témáját, jelen tanulmány a 2-3. pont megvilágítására szolgál, azaz a közép-magyarországi, elsősorban a budapesti gyógyfürdők 
igénybevételének és a balneo kozmetikumvásárlás folyamatának, különös tekintettel a Budapest Spas termékcsalád leírására, illetve az erre ható tényezők közötti kapcsolatrendszer statisztikai módszerek segítségével történő elemzésére irányul.

\section{Irodalmi áttekintés}

A víz sokféleképpen tesz jót az ember számára, például a fogyasztásával, a létfontosságú hidratálással, az otthoni fürdőzéssel, a hidroterápiával (például úszással, vízen való lebegéssel), mivel megnyugtató hatással van a pszichére a látványával, a sós, tengeri levegő belélegzésével (Ivens, 2018). A gyógyfürdő elsősorban gyógyító célokat szolgál, de üdülési, tisztasági, illetve felfrissítési célokra is felhasználható. A fürdő nagyon fontos szerepet játszik az egész testápolásban, mivel a tisztálkodáson kívül a fürdőnek élénkítő vagy nyugtató hatása is van. A fürdők lehetnek tisztítófürdők, nyugtatófürdők, frissítő-üdítő fürdők, bőrápoló kozmetikai fürdők és házilag készíthető gyógyfürdők. A gyógyfürdők vonatkozásában a testápolás egyenlő az egészségápolással (Romváry, Gerö, 1985).

A gyógyvizek és a balneo kozmetikumok használata a wellness és spa tevékenységekhez köthetőek elsősorban, mivel a wellness olyan egészségtudatos életforma, melyben a wellnesst gyakorló jó közérzetet biztosít önmaga számára, ezért a wellness testi-lelki kiegyensúlyozottságra törekszik. A wellness centrumok általában fürdőt, masszázst, szaunát, sportlehetőségeket, kondicionáló tornákat, szépségszalont, diétás étkezést, relaxációs, illetve szórakozási lehetőséget biztosítanak látogatóiknak, melynek müködéséhez nem szükséges termál ásványvíz, de sokszor gyógyfürdöben, gyógyhelyen müködik (Bender, 2008). A wellness szemlélet a kozmetikában a kezelések komplexitását jelenti, mivel a wellness túlmutat az egyszerü szépségápoláson a kozmetikában, hiszen a kezelések alatt megújul a test és a lélek is (Fási, 2015).

Különböző wellness szolgáltatásokat, - akár holisztikus szemléletben is - igénybe lehet venni annak érdekében, hogy a víz rekreációs hatása élvezhető legyen. Ilyen szolgáltatások közé tartoznak a fürdők, a szaunák és gőzfürdők, a relaxáció és a terápiák (fürdők, (szépítő) pakolások, méregtelenítő kúrák, például oxigénterápia, léböjtkúra, masszázsok, terápiák mozgásszervi panaszokra, például gyógy- és gerinctorna, alternatív terápiák, például meditáció, akupunktúra), a mozgáskultúra, a kozmetikai kezelések és a wellness-konyha, táplálkozási tanácsadás, amelyeknek számos változata létezik (Heim (Szerk.) 2008, Brown, White, 2008). A fürdés a kozmetika egyik alapja is (Kunze, 1973). A spa olyan hely, amely természetes forrás-, gyógy-, vagy tengervízzel rendelkezik, továbbá a víz jótékony hatásait használják fel többek között regenerálódásra, kikapcsolódásra, ellazulásra, gyógyulásra, megszépülésre vagy érvényesülhet ez az összes hatás egyszerre is. A spa általában egy szállodával vagy wellness központtal egybekötött komplexum, ahol különbözö medencék és vizes kezelések várják a látogatókat. A vizes kezelések gyüjtőnevét is takarja a fogalom, amelyhez az egyszerü fürdőzésen kívül olyan különleges kezelések sorolhatóak, mint például a gőzfürdő, a Kneippkúra, a vízben vagy vízzel végzett terápiák, mint a balneo-, illetve a hidroterápia. Ma már elfogadott az is, hogy sok helyen a wellness szolgáltatásokat, azaz a különböző masszázsokat és testkezeléseket is sokszor spa-ként emlegetik a köztudatban. Ilyen példák lehetnek a kávés, csokoládés és egyéb aromamasszázsok, vagy az ún. spa kezelések, amelyet az Amerikai Egyesült Államokban a '80-as években fejlesztettek ki, ahol különböző vízből nyert anyagokat (alga, só, gőz, iszap, ásványok) használnak fel a relaxációhoz és a gyógyításhoz. Tovább színesítik a spa világát a különbözö pakolások, szín- és fényterápiák és étrendek. A spa otthoni felhasználása a kozmetikai ipar által kifejlesztett olyan kozmetikumok használatát jelenti, melyek a vízből nyert természetes anyagok (például iszap, ásványok) tubusba zárásával házhoz viszik a spa értékeit (Kurland, 2020, Kertész (Szerk.), 2004, Kovács (Szerk.), 1985).

A víz még ma is fontos összetevője a spa-élménynek, de a modern spa-intézmények egyre inkább az egészség megközelítésének egy összetett és holisztikus módját választják, ami magában foglalja a szolgáltatásokat, a kezeléseket, tovább az étrendet is a test, a lélek és a szellem kiegyensúlyozása céljából. A spa-élményt nem elszigetelt kezelések összességeként definiálják, hanem a jó közérzethez és a fitneszhez vezető valódi holiszikus megközelítésként. A modern spa egyik alapja tehát a szépség, amely a különböző kezelések (például arckezelés, testtekercselés) által segítenek a test és a bőr megtisztításában és kényeztetésében. A kezelések nem csupán a felszínre hatnak -, hiszen ha az ember 
jól néz ki külsőleg, akkor jól is érzi magát a bőrében -, és ez a kölcsönhatás testileg is és lelkileg is előnyére válik. A harmónia az olyan kezelések fő jegye, mint a masszázs, amelyben az érintés gyógyító erejét hasznosítják, segítenek az ellazulásban, illetve harmóniát teremtenek (Kertész (Szerk.), 2004).

A fürdőzés egyébiránt egy nagyon régi szokás, amely mind a testet, mind a lelket frissíti (Heim (Szerk.), 2008). A (gyógy)víz külsőleg kedvező hatást gyakorol testre és lélekre, mivel ellazít, megnyugtat (Shutt, 2002). A balneoterápia a betegségek gyógyításán kívül felfrissülésre is alkalmas. A szauna forró levegője vagy forró vízgőze mind a stressz ellen, mind természetes testápoló szerként hat, mivel az izzadással és a különbözö hidegvizes kezelésekkel a bőr egyrészt alaposan megtisztul, másrészt megduzzadnak és le is válnak a bőr felső rétegében a szarusejtek (Shutt, 2002, Weiß, 2007, Czetö, Pauer, 2013).

A víz egészséges ingerhatásai a hőingerek, a fizikai ingerek és a kémiai ingerek. A hőingerek a víz hőmérséklete révén keletkeznek attól függően, hogy milyen hatást szeretnénk elérni. A külső felhasználás történhet hideg, meleg, de meleg és hideg víz felváltásával is. Fizikai ingerek a hidrosztatikus nyomás által keletkeznek, vagyis a víznek a bőrre gyakorolt nyomása által. Fürdéskor érezhetővé is válik, mivel ilyenkor a víztömeg ránehezedik testünkre, amelyet szinte súlytalanná is tesz. Kémiai ingerek abban az esetben jönnek létre, ha a víz elég hosszan hat ránk. Ilyenkor a bör felduzzad, és fokozódik a felvevőképessége, ezért könnyebben be tudnak hatolni a bőrbe a vízben oldott anyagok (ásványok, sók), továbbá a vízhez hozzáadott hatóanyagok. Például ilyenek a gyógynövény kivonatok vagy illóolajok is, amelyek könnyebben érvényre tudják juttatni rekreációs, de gyógyító tulajdonságaikat is (Shutt, 2002).

A biológiai tényezők szerepe a gyógyvizek és gyógyvíz alapú kozmetikumok fogyasztásában döntően a fogyasztóhoz, az egyénhez kapcsolódik. A szem által, vagyis a látás útján történő érzékelés a balneo kozmetikum, a gyógyfürdők fényviszonyai, illetve magának a gyógyfürdőnek, a gyógyvíznek a látványával kapcsolatos. Az érzékelés során a kozmetikum/gyógyfürdő és berendezésének színe, mérete, formája, a gyógyvíz átláthatósága érzékelhető. Ízlelés útján a gyógyvíz ivókúrák során elfogyasztott gyógyvíz íze minősíthető. Szaglás által a párolgó gyógyvíz, a kozmetikai termék és a gyógyfürdőkben alkalmazott illóolajak és aromaterápiás gyógynövények illata/szaga válik az érzékelés tárgyává. Az izmok és a bőr a gyógyfürdők medencéiben a gyógyvíz által a bőrre és az izmokra gyakorolt víznyomást érzékelik, illetve a kozmetikai anyag bőrre gyakorolt hatását, például a masszázsok során. Hallás útján a gyógyfürdőkben kibocsátott hangok érzékelhetőek. Ilyenek például a jacuzzi medencék, pezsőfürdők pezsgése, azaz hanghatása (Lehota, 2001 alapján saját példagyüjtés).

A saját elméleti modell (1. ábra) fejlesztésének folyamatának kialakításában a következő forrásmodellek voltak jelentősek:

1. Engel-Kollat-Blackwell-féle vásárlási magatartás modell, mert teljes körüen mutatja be a fogyasztói/vásárlói magatartás döntési folyamatát (Engel et al., 1973 p. 128., Lehota, 2001, Bauer, Berács, 1998).

2. A Dembkowski-Hanmer-Lloyd-féle fogyasztó beállítódás alapján készült modell, mert értékeli a terméktulajdonságokat, illetve az egyéni érdekeltség, az észlelt fogyasztói hatékonyság tényezőit és a szituációs igényeket, mint változókat is bemutatja (Dembkowski, Hanmer-Lloyd, 2010, Majláth, 2009).

3. Az egészség újradefiniálását megcélzó Meikirch-modell, mivel az egészség a jóllét állapota, amely az egyéni képességek, az életút során keletkező kihívások, valamint a társadalmi és környezeti befolyásoló tényezők közötti kölcsönhatások eredménye. Ez utóbbi része a rekreáció is (Bircher, Hahn, 2016, Kiss, 2018, Notarnicola et al., 2019).

\section{Anyag és módszer}

Kutatási módszerekként került alkalmazásra az irodalomfeldolgozás, a szekunder kutatás, illetve primer kutatásként a kvalitatív kutatás, amelyeket kiegészített a kvantitatív kutatás módszere is. A kvalitatív kutatások során alkalmazott módszerek az online tartalom megfigyelés és az egyéni interjúk. 
A saját elméleti modell (1. ábra) újdonsága, hogy teljes és részleges (nem kozmetikai termékcsoportokra vonatkoztatott) fogyasztói/vásárlói forrásmodelleket adaptált a gyógyfürdőkre és balneo kozmetikumokra irányuló fogyasztói/vásárlói magatartás modell megalkotásakor. A modell elsősorban a rekreáció szerepét vizsgálja.

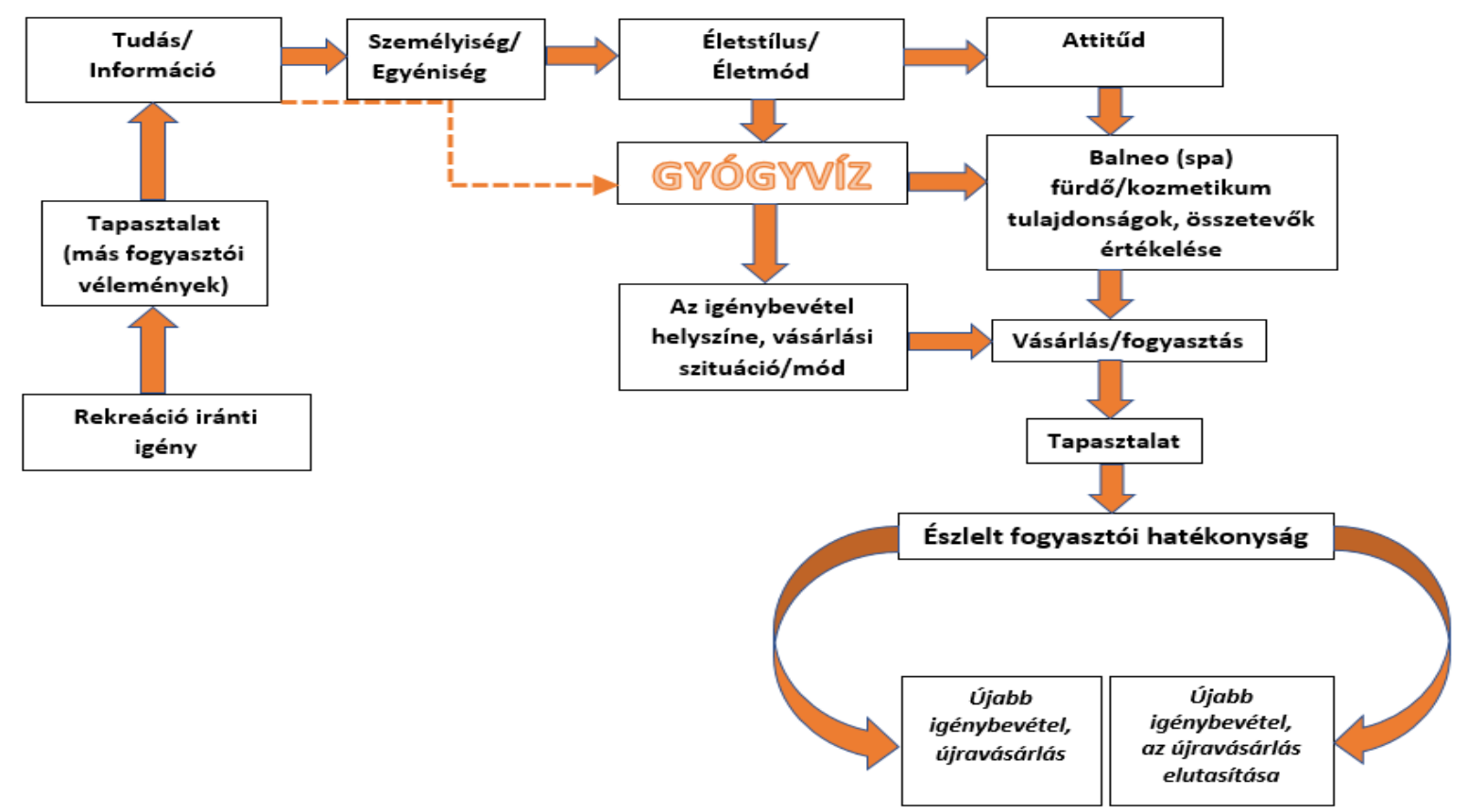

1. ábra: Gyógyfürdö/balneo (spa) kozmetikum fogyasztói magatartás saját modell

Figure 1: Balneo (spa) cosmetics consumer behaviour own model

Forrás: Saját kutatás, szerkesztés az. Engel-Kollat-Blackwell-féle vásárlási magatartás modell (Engel et al., 1973), a Dembkowski-Hanmer-Lloyd-féle fogyasztói beállitódás alapján készült modell (Demkowski, HanmerLloyd, 2010) és a Meikirch-modell (Bircher-Hahn, 2016), mint forrásmodellek alapján, 2020

A két kvalitativ kutatási módszer fó célkitüzése, hogy a saját elméleti fogyasztói magatartás modell tényezöi miként befolyásolják a gyógyvizek és a balneo (spa) kozmetikumok preferálását.

\subsection{Balneo kozmetikumokkal kapcsolatos online tartalom megfigyelés}

Azért került ez a módszer kiválasztásra, mert az online fogyasztói vélemények, mint tartalom megfigyelésével, külső szemlélőként, új motívumok, változók tárhatóak fel a balneo kozmetikumok fogyasztásával, vásárlásával kapcsolatban. Ennek tükrében a Krémmánia c. weboldal lett elemezve, amely egy-egy kozmetikai termékre vonatkozóan eltérő és hasonló fogyasztói/vásárlói magatartás mintákat mutat be. Azért is került kiválasztásra ez az alternatív forrásként jellemezhető weboldal, mert a balneo (spa) kozmetikumokkal kapcsolatban nem található olyan tudományos forrás, ahol ilyen jellegü fogyasztói/vásárlói vélemények kerültek bemutatásra és feldolgozásra.

Ennek a kutatásnak a célja ezért az online tartalom megfigyelés módszerével a Krémmánia oldalán (Krémmánia, n.a.) néhány balneo kozmetikummal kapcsolatos fogyasztói vélemény, azaz egy 50 fös fogyasztói minta alapján történt balneo kozmetikumokra irányuló fogyasztói/vásárlói magatartás tényező beazonosítása, különös tekintettel a Budapest Spas termékcsaládra. Az online felületen történő keresőszavak a következők voltak: spa, balneo, gyógyvíz, gyógyfürdő, Budapest Spas, Omorovicza, globális márkák, drogéria saját márka. A kutatás fö kérdése, hogy mely tényezök hatására dönt a kozmetikumvásárló/fogyasztó a kiválasztott balneo kozmetikum mellett.

A mintában szereplö fogyasztók fó jellemzöit tekintve a minta korcsoportja olyan 18 év feletti nöi balneo kozmetikum vásárlókból/használókból állt, akik kipróbáltak a bőrtípusuknak megfelelő balneo (spa) kozmetikumokat különböző börproblémáikra. 


\subsection{Egyéni interjúk}

Az egyéni interjúk a gyógyvizek és a gyógyvíz alapú kozmetikumok vásárlók/fogyasztók általi kiválasztásának az okait azonosítják. Az elméleti modell minden tényezője vizsgálható általuk, azaz a saját elméleti modell ezekkel a módszerekkel validálható, a vizsgálatoknak megfelelően módosítható. A módszer célkitüzése, hogy mely tényezők hatására választja a fogyasztó/vásárló a budapesti gyógyfürdőket, illetve a gyógyvíz alapú kozmetikai termékeket, különös tekintettel a Budapest Spas balneo kozmetikumcsaládra.

A kutatási kérdések a „miért”-ekre, a vásárlási és fogyasztási motivációkra keresték a választ. Módszer tekintetében féligstrukturált egyéni interjúk lettek lefolytatva. A maximális variáció, mint mintavételi módszer került alkalmazásra, mely a lehető legkülönbözőbb mintaalanyokat keresi a legszélesebb merítéssel.

A kiválasztás során az alábbi ismérvcsoportok kerültek meghatározásra:

Elsődleges szegmentációs ismérvek voltak a különböző és hasonló (szocio)demográfiai jellemzők, mint a nem, lakhely, családi állapot, munkakör, nettó jövedelmi kategória, legmagasabb iskolai végzettség, illetve a másodlagos szegmentációs ismérv, hogy van-e rekreáció iránti igénye az interjúalanynak.

A mintavételt tekintve a föbb ismérvek: $\mathrm{n}=20$ (14 nö, 6 férfi), korcsoport: olyan 18 év feletti a középmagyarországi régióból (15 fö Budapestről és 5 fő Pest megyéből) származó balneo kozmetikum vásárlók/fogyasztók, akiknek van rekreáció iránti igényük, és hajlandóak is voltak a kutatásban részt venni. Az egyéni interjúk 2021.01.17-től 02.11-ig lettek lebonyolítva - a pandémia miatt - elsősorban telefonon és online, illetve szük körben személyesen.

Az egyéni interjúk felállított hipotézise a következö volt: a fogyasztók gyógyvizekkel kapcsolatos beállitottságának a jellemzöi beazonosíthatóak a gyógyfürdökkel, gyógyvíz alapú kozmetikumokkal kapcsolatos döntéseik meghozatalakor.

\section{Eredmények}

\subsection{Balneo kozmetikumokkal kapcsolatos online tartalom megfigyelés}

$\mathrm{Az}$ online tartalom megfigyelés legfontosabb eredménye a saját elméleti modell tényezőinek megerősítése a balneo kozmetikumok vásárlását és fogyasztását (használatát) befolyásoló változók feltárása által.

Az 50 fö fogyasztói véleménye alapján beazonosított balneo kozmetikum vásárlással és fogyasztással kapcsolatos fő változók az adatok összegyüjtése és elemzése során a keresés (cél), a beszerzés, a fajta/funkció, az összetevők, a márka, az ár/összehasonlítás, jövedelem, csomagolás/kiszerelés, illat, textúra/állag, tartalom színe, hatás, használat (felhasználás), emlékezet, képzettársítás (asszociáció), értékelés, termékérzet, újravásárlás, ajánlás, a vásárlás helyszíne, módja, korcsoport, bőrtípus, bőrproblémák, melyek az egyes kapcsolódó saját elméleti modell tényezőknek lettek megfeleltetve ( 1 . táblázat).

A Budapest Spas termékcsaládot tekintve a fogyasztók elsősorban a különböző kézmüves szappanokat (Széchenyi, Gellért, Rudas) és tusfürdőket részesítették előnyben. 
1. táblázat: Online fogyasztói vélemények kapcsolata és a saját elméleti modell tényezök közötti kapcsolat Table1: The relationship between online consumer opinions and self-theoretical model factors

\begin{tabular}{|c|c|}
\hline Saját modell tényezö & $\begin{array}{c}\text { Az online tartalom megfigyelés során } \\
\text { beazonosított változók }\end{array}$ \\
\hline Rekreáció iránti igény & Keresés (cél) \\
\hline $\begin{array}{l}\text { Tapasztalat (más fogyasztói } \\
\text { vélemények) }\end{array}$ & Ajánlás \\
\hline Tudás/Információ & $\begin{array}{l}\text { Fajta/Funkció } \\
\text { Összetevők } \\
\text { Márka } \\
\text { Ár/Összehasonlítás } \\
\text { Jövedelem } \\
\text { Csomagolás/kiszerelés } \\
\text { Illat } \\
\text { Textúra/Állag, Tartalom színe }\end{array}$ \\
\hline Személyiség/Egyéniség & \multirow{2}{*}{$\begin{array}{l}\text { Korcsoport, Bőrtípus, Bőrproblémák, Jövedelem } \\
\text { A bőrtípus/bőrproblémák az egyén saját } \\
\text { jellemzői, amelyekre különböző balneo } \\
\text { kozmetikumokat használhat az életstílusának } \\
\text { megfelelően. }\end{array}$} \\
\hline Életstílus/Életmód & \\
\hline Attitüd & $\begin{array}{l}\text { Keresés, beszerzés, újravásárlás, a vásárlás } \\
\text { helyszíne, módja }\end{array}$ \\
\hline $\begin{array}{l}\text { Szolgáltatás és } \\
\text { terméktulajdonság/összetevő } \\
\text { jellemzők értékelése }\end{array}$ & Értékelés, Termékérzet \\
\hline $\begin{array}{l}\text { Az igénybevétel helyszíne, } \\
\text { vásárlási szituáció, mód }\end{array}$ & A vásárlás helyszíne, módja \\
\hline Vásárlás/fogyasztás & Beszerzés \\
\hline Tapasztalat & $\begin{array}{l}\text { Hatás } \\
\text { Használat (felhasználás) } \\
\text { Emlékezet, Képzettársítás (asszociáció) }\end{array}$ \\
\hline Észlelt fogyasztói hatékonyság & Értékelés, Termékérzet \\
\hline $\begin{array}{l}\text { Újabb igénybevétel, újravásárlás, } \\
\text { illetve ennek az elutasítása }\end{array}$ & Újravásárlás/Újrarendelés \\
\hline
\end{tabular}

Forrás: Saját kutatás, szerkesztés az Engel-Kollat-Blackwell-féle vásárlási magatartás modell (Engel et al., 1973), a Dembkowski-Hanmer-Lloyd-féle fogyasztói beállitódás alapján készült modell (Demkowski, HanmerLloyd, 2010) és a Meikirch-modell (Bircher-Hahn, 2016), mint forrásmodellek alapján (2020) és a Krémmánia (n.a.) alapján (2021)

Az 1. táblázatban szereplő balneo kozmetikumok vásárlásával és használatával kapcsolatos változók végül 5 fö csoportba lettek sorolva, azaz

1. A balneo kozmetikumok keresésének, használatának a célja, mint például korcsoportoknak, bőrtípusra, börproblémákra történő ajánlás.

2. A beszerzés forrása, azaz a vásárlás helyszíne, módja.

3. A balneo kozmetikum tulajdonságai, mint

- a kozmetikum fajtája (például arcápolási, testápolási termékek), funkciója (például hidratálás, ránctalanítás, rekreáció);

- a balneo kozmetikum összetevői (például gyógyvíz, iszap, gyógynövények, gyümölcsök, zöldségek);

- a balneo kozmetikum márkája (például Budapest Spas, Omorovicza);

- a vizsgált kozmetikum ára, illetve összehasonlítása más kozmetikumokkal;

- a fogyasztó rendelkezésére álló jövedelem, mint a vásárlási döntések felső korlátja;

- a kozmetikum csomagolása, kiszerelése; 
- a balneo kozmetikumot jellemző illat;

- a balneo kozmetikum textúrája, állaga;

- a csomagolásban található kozmetikum textúrájának (például arckrém, testápoló) a színe.

4. A kozmetikum fogyasztása, azaz

- használata, amely lehet rendszeres vagy ideiglenes, felhasználási helye (egy vagy több testrészre);

- termékérzet megjelenése a bőrön (például bizsergető érzés a kozmetikumban található mentol miatt);

- hatása (például hidratáltság, ránctalanítás);

- emlékezet, asszociáció, amelyet a fogyasztó a korábbi balneo kozmetikuma használatához társít.

5. A balneo kozmetikummal kapcsolatos visszacsatolás, tapasztalatok, a jövőbeni vásárlás vagy annak az elutasítása:

- termékértékelés a használat után;

- újravásárlás, illetve továbbajánlás más fogyasztóknak.

\subsection{Egyéni interjúk}

Az egyéni interjúk főbb eredményei a következők lettek:

I. A saját elméleti modell tényezői az egyéni interjúk eredményeinek kiértékelése alapján megerősítést nyertek.

II. Új eredmények az új változók feltárása, beazonosítása, gyógyfürdők igénybevétele a tudatosan eltöltött szabadidőben, illetve különböző interjúalany típusok beazonosítása.

1. Az egyéni interjúk alapján beazonosított új tényezők az alábbiakban foglalhatóak össze:

- Az igénybevétel oka a rekreáció, regeneráció, prevenció, illetve a kíváncsiság;

- Az igénybevétel korlátai a honvágy és a magas belépőjegy árak;

- Otthoni gyógykúrák/wellness alkalmazása, különösen a pandémia időszakában az egyéni lehetőségekhez mérten;

- Komplex élményhatás, azaz a gyógyfürdőkben rendelkezésre álló lehetőségek hatása a fogyasztó testi-lelki-szellemi harmóniájára;

- Professzionális szemlélet, mivel Magyarország „gyógyvizes ország”, és erről több fogyasztó szakkönyekből is tájékozódik;

- Látens vágyak kielégítésének az igénye, mint például a magas színvonalú modern kozmetikai kezelések és a spa hotelekben rendelkezésre álló lehetőségek közötti differencia áthidalása a különböző fogyasztói igények kielégítése irányában;

- Szakemberek által ajánlott gyógyfürdők és/vagy balneo kozmetikumok;

- Balneo kozmetikumok vásárlása gyógyfürdőkben, amelyekhez különböző asszociációkat társít a fogyasztó az életéből, emlékezetéből, illetve az általa elképzelt gyógyfürdőzés lehetőségeiről;

- A gyógyfürdők igénybevételét a fogyasztók rendelkezésére álló szabadidő nagymértékben befolyásolja;

- A természeti és az épített, mesterséges környezet is hat a fogyasztók rekreációjára, mivel a gyógyfürdők különbözö földrajzi-természeti környezetben találhatóak, amelyek nem mindegyike felel meg minden fogyasztó ízlésének és elképzeléseinek;

- A gyógyfürdők külső környezete és a belső tere is kontraszthatásban állhatnak egymással az egyik vagy a másik javára;

- A spa hotelekben különböző turisztikai lehetöségeket is igénybe vehetnek a fogyasztók, amelyek további testi-lelki-szellemi felfrissülést és kikapcsolódást jelenthetnek számukra;

- Végül szakorvos által felírt gyógykezeléseket (OEP) is igénybe vehetnek a különböző egészségi problémáikra a fogyasztók, amelyek orvosolhatóak a gyógyfürdőkben történő kezelések által.

2. Gyógyfürdők igénybevétele a tudatosan eltöltött szabadidőben (holisztikus szemléletben)

A gyógyfürdőkkel kapcsolatos saját elméleti modelltényezők és a beazonosított új, illetve újszerü determinánsok alapján a gyógyfürdők igénybevételét befolyásolja a rekreáció, a prevenció, a 
regeneráció és a tudatosan eltöltött szabadidő, amelyek körkapcsolatban állnak egymással. A fogyasztó, amíg nem betegszik meg fizikailag/mentálisan, addig a prevenció játszhat hangsúlyos szerepet az életében, ellenkező esetben már a regeneráció. A tudatosan eltöltött szabadidő a gyógyfürdő tevékenységek rendszeres igénybevételét, mint kialakult életformát jelenti.

- A gyógyfürdők a rekreáció szempontjából a testi-lelki megújulásban;

- A prevenció a betegségek megelőzésében, azaz az egészség védelmében és az egészségtudatosságban;

- A regeneráció a fizikai és mentális betegségek kezelésében, illetve az orvos által felírt gyógykezelések igénybevételében tudnak segítséget nyújtani;

- A tudatosan eltöltött szabadidő a balneo kozmetikai/gyógyfürdő szolgáltatások igénybevételére, a külső és belső (a gyógyfürdőkön kívül és belüli) környezeti (természetes és épített) értékek élményhatásának átélésére, illetve a turisztikai programokon való részvételre biztosítanak lehetőséget, továbbá a gyógyfürdők látogatása egyben a tudatos életforma részévé is válik ( 2 . ábra).

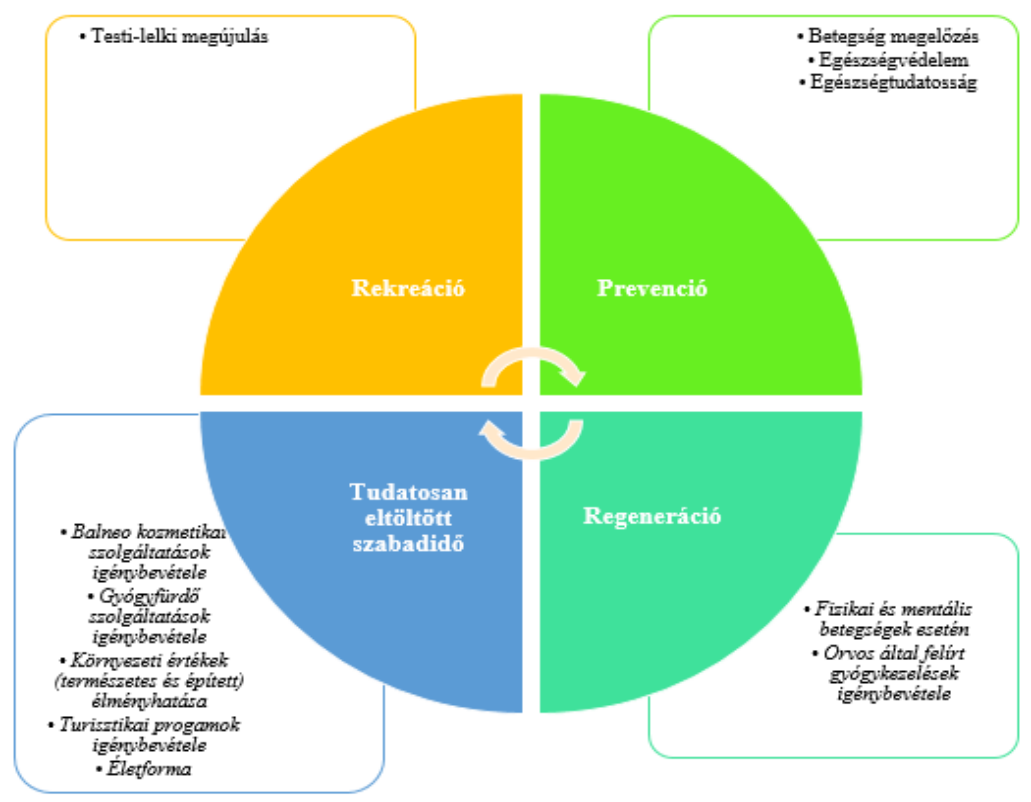

2. ábra: Gyógyfürdők igénybevétele a tudatos szabadidö-eltöltésben holisztikus szemléletben Figure2: Use of spas in conscious leisure in a holistic approach

Forrás: Saját kutatás, szerkesztés, 2021

3. Interjúalany típusok beazonosítása

A 20 interjúalany interjúkérdésekre adott válaszai, illetve további - a témával kapcsolatos véleménye alapján 4 típus rajzolódott ki, mivel a gyógyfürdőket igénybevevők, illetve a balneo kozmetikumokat vásárlók/fogyasztók kategóriája nem minden esetben fedte le egymást, továbbá nem minden fogyasztó szenved olyan fizikai/mentális betegségben, amelyre javasoltak, például szakorvos által a gyógyfürdők szolgáltatásai, vagy amelyre igénybe is venné azokat (2. táblázat). Ezek a típusok természetesen nem jelentenek meghatározott szegmenseket, csupán csoportosításirányokat.

Minden egyéni interjúalany egészségtudatosnak vallotta magát, illetve rendelkezett bizonyos mértékü szabadidővel, továbbá korábban igénybe vett már gyógyfürdő szolgáltatásokat is rekreáció iránti igényéből kifolyólag, ha volt rá lehetősége (a pandémiás időszak miatt egyelőre a múltra vetítve volt csak értelmezhető a kérdés). 
16 interjúalanynak jelenleg is van rekreáció iránti igénye, 4-nek korábban volt ilyen gyógyvizekre irányuló rekreációs igénye, de a koruknál fogva már jobban szeretnek az otthonuk „biztonságában” lenni akkor is, ha nincs pandémiás időszak.

A 4 típus közötti jelentős különbségek a fizikai/mentális betegségek meglétében, illetve abban lelhető fel, hogy a gyógyfürdők helyszínén, amikor igénybe veszi a gyógyfürdő szolgáltatásokat is, vásárol/használ-e a fogyasztó balneo kozmetikumokat. Ezeknek megfelelően a következő 4 típus lett beazonosítva (2. táblázat):

1. típus: Nincs fizikai/mentális betegsége és nem vásárol/használ balneo kozmetikumokat. Ennek okai például, hogy nincs olyan problémája, amelyre jelenleg használná, vagy drágának tartja ezeket a kozmetikumokat.

2. típus: Nincs fizikai/mentális betegsége, de vásárol/használ balneo kozmetikumokat, amelynek okai például, hogy van olyan problémája, amelyre jelenleg használná, vagy hajlandó felárat is fizetni ezekért a kozmetikumokért, továbbá előfordult korábban, hogy gyógyfürdőkben is vásárolt már ilyen termékeket.

3. típus: Van fizikai/mentális betegsége, de nem vásárol/használ balneo kozmetikumokat. Ennek okai például, hogy van olyan problémája, amelyre jelenleg használná, de drágának tartja ezeket a kozmetikumokat.

4. típus: Van fizikai/mentális betegsége és vásárol/használ balneo kozmetikumokat is, melynek okai például, hogy van olyan problémája, amelyre jelenleg használná, és hajlandó felárat is fizetni ezekért a kozmetikumokért, továbbá előfordult korábban, hogy gyógyfürdőkben is vásárolt már ilyen termékeket.

2. táblázat: Interjúalany típusok beazonositása

Table2: Identification of interterviewee types

\begin{tabular}{|l|l|l|l|l|l|}
\hline $\begin{array}{c}\text { A beazonosított } \\
\text { típus sorszáma }\end{array}$ & $\begin{array}{c}\text { Egészség } \\
\text { tudatosnak } \\
\text { vallja } \\
\text { magát? }\end{array}$ & $\begin{array}{c}\text { Van-e } \\
\text { rendelkezésére } \\
\text { álló } \\
\text { szabadideje? }\end{array}$ & $\begin{array}{c}\text { Van-e } \\
\text { fizikai/ } \\
\text { mentális } \\
\text { betegsége? }\end{array}$ & $\begin{array}{c}\text { Igénybe vett-e } \\
\text { már korábban } \\
\text { gyógyfürdón } \\
\text { szolgáltatásokat? }\end{array}$ & $\begin{array}{c}\text { Vásárol/használ- } \\
\text { e jelenleg balneo } \\
\text { kozmetikumokat? }\end{array}$ \\
\hline 1. & $\mathrm{X}$ & $\mathrm{X}$ & & $\mathrm{X}$ & \\
\hline $\mathbf{2}$. & $\mathrm{X}$ & $\mathrm{X}$ & & $\mathrm{X}$ & $\mathrm{X}$ \\
\hline $\mathbf{3 .}$ & $\mathrm{X}$ & $\mathrm{X}$ & $\mathrm{X}$ & $\mathrm{X}$ & \\
\hline 4. & $\mathrm{X}$ & $\mathrm{X}$ & $\mathrm{X}$ & $\mathrm{X}$ & $\mathrm{X}$ \\
\hline
\end{tabular}

Forrás: Saját kutatás, szerkesztés (2021)

Az egyéni interjúk hipotézisének vizsgálatára vonatkozóan a kapott eredmények alapján

1. Be lettek azonosítva a modell szerinti változók;

2. Fel lettek tárva a modell-tényezőktől eltérő új determinánsok is;

3. Fel lett tárva a gyógyfürdők preferálása és a tudatosan eltöltött szabadidő közötti kapcsolat;

4. A 4 fogyasztó/vásárlótípus a környezet- és egészségtudatosság vonatkozásában „a minek vallja magát és hogyan cselekszik" összefüggés rendszerében lett vizsgálva.

A fenti 4 pont alapján a felállított hipotézis (A fogyasztók gyógyvizekkel kapcsolatos beállitottságának a jellemzői beazonosithatóak a gyógyfürdökkel, gyógyvíz alapú kozmetikumokkal kapcsolatos döntéseik meghozatalakor) igaznak bizonyult.

\subsection{Az elméleti és a kutatási modell közötti kapcsolat bemutatása}

1. Az irodalomkutatás alapján létrehozott modellhez képest (1. ábra) a kvalitatív kutatások által módosított modellben (3. ábra) a szabadidő/szabadság és a képzettársítás új tényezőkként jelentek meg.

2. A kvalitatív vizsgálatok által a következő tényezők lettek kiegészítve: 
- Az igénybevétel oka a rekreáción kívül a prevenció, a regeneráció, illetve a kíváncsiság és a látens igények, vágyak kielégítése.

- A tapasztalat a különböző szakemberek ajánlásával került kiegészítésre.

- A tudás/információ a belépőjegyek magasabb árainak észlelésével, a földrajzi távolsággal (a fogyasztó otthona és a kiválasztott gyógyfürdő között), illetve a professzionális szemlélettel (például gyógyfürdőkkel kapcsolatos szakkönyvek tanulmányozásával, a témában való jártassággal) bővült.

- Az életstílusra, életmódra életformaként asszociáltak az interjúalanyok. Ezek a kifejezések egymás szinonimái.

- A balneo (spa) fürdő, illetve kozmetikum tulajdonságok, összetevők értékelését a rendelkezésre álló lehetőségek és a gyógyfürdőn belüli, illetve a gyógyfürdőn kívüli környezeti élményhatások egészítették ki.

- Az igénybevétel helyszínét, a vásárlási szituációt, módot tovább pontosította az otthoni gyógykúrák, wellness (például iszappakolás, aromafürdő), illetőleg a különböző spa hotelekben megszálló vendégek számára a külső helyszíneken igénybe vehető turisztikai programok, továbbá a gyógyfürdőkben rendelkezésre álló orvosi kezelések.

- A fogyasztói tapasztalatok az egyéni interjúk alapján pozitívak és negatívak is lehetnek. Volt olyan válaszadó is, akit erős honvágy gyötört egy spa hotelben, és haza kellett emiatt utaznia. A spa hotelek a gyógyfürdőrészlegükkel együtt komplex élményhatást nyújthatnak a vendégeknek.

- Az észlelt fogyasztói hatékonyság tényezőt kiegészítette az alkalmazási/használati idő hossza is mind a gyógyfürdők, mint a balneo kozmetikumok hatásosságát tekintve.

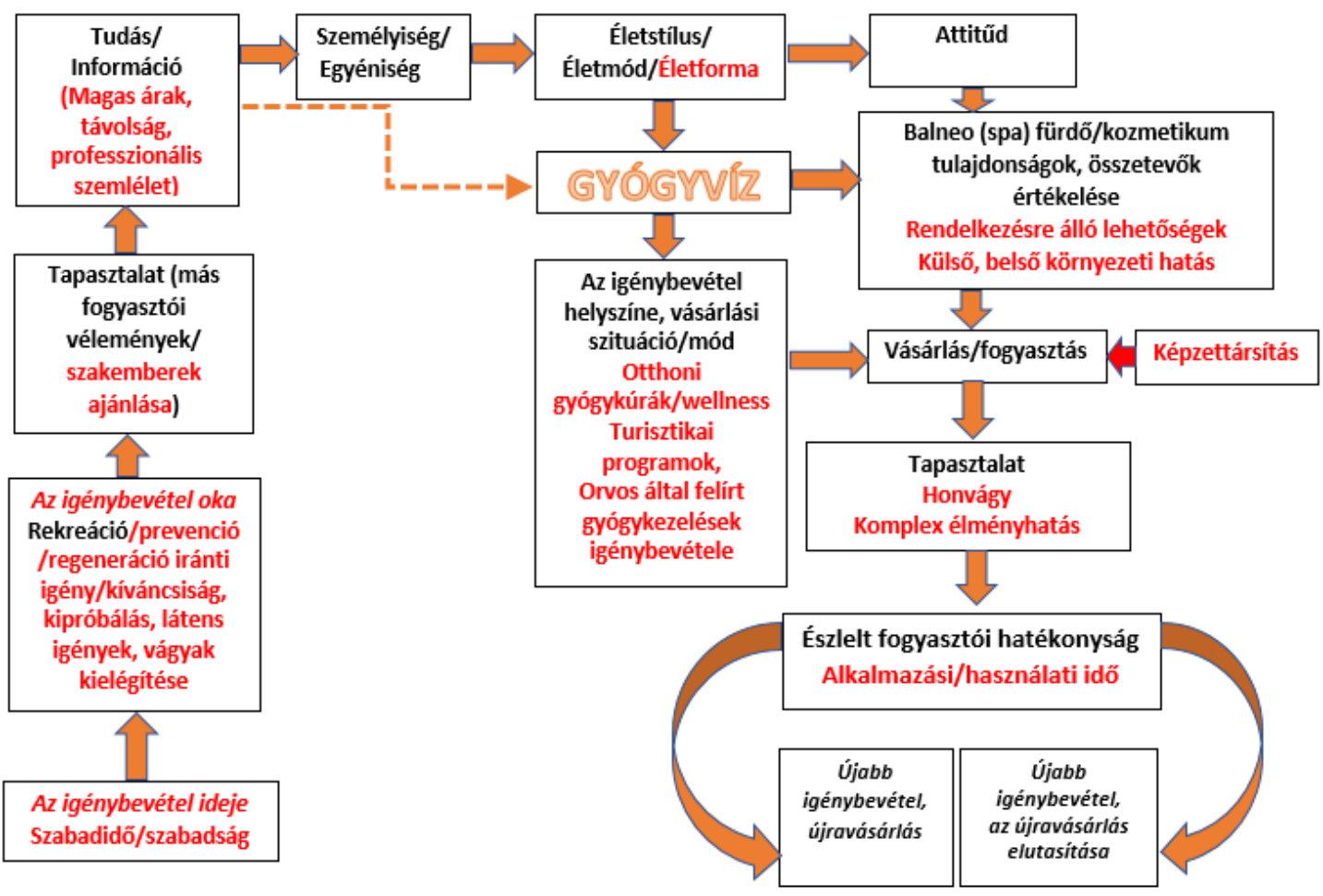

3. ábra: A saját elméleti modell módositása a kvalitatív kutatás (egyéni interjúk) után Figure3: Modification of own theoretical model after qualitative research (individual interviews)

Forrás: Saját kutatás, szerkesztés, 2021 


\section{Következtetések, javaslatok}

A budapesti gyógyfürdők igénybevételét és a balneo kozmetikumok vásárlását és fogyasztását, különös tekintettel a Budapest Spas termékcsaládra többféle tényező befolyásolja, amelyek új tényezőkként vagy kiegészítésként jelentek meg a kutatási modellben, azaz a gyógyvizekre nyitott vásárlókat, fogyasztókat a szabadidő tudatos eltöltése indukálja a gyógyfürdőkkel kapcsolatos rekreációs, prevenciós, regenerációs igényük és a kíváncsiságuk kielégítésére, hogy igénybe vegyék ezeket a szolgáltatásokat. A gyógyvizekre irányuló fogyasztói, vásárlói döntéshozatal komplex magatartásrendszert, a különböző hatótényezők közötti kapcsolatrendszert foglalja magában.

A kutatás következő fázisa az online kérdőíves megkérdezés, amely során 218 föt sikerült lekérdezni 2021. április 11. és május 13. között. A kvantitatív megkérdezésekkel a kutatási modell validálhatóvá válik további hipotézisek felállítása és vizsgálata által a témában, mivel a gyógyvizek a középmagyarországi régióban is különösen hangsúlyos szerepet kaptak a fürdőközönség és a gyógyvíz alapú kozmetikum vásárlók, fogyasztók számára a széles körben elérhető fürdő- és balneo kozmetikum választék rendelkezésre állása alapján.

\section{5. Összefoglalás}

A saját elméleti modell a kvalitatív kutatások eredményeinek értelmezésén és elemzésén keresztül alakult kutatási modellé, mely utóbbiban új modell tényezőként jelent meg a szabadidő és a képzettársítás. $\mathrm{Az}$ online tartalom megfigyelések a balneo kozmetikumok vásárlásának és fogyasztásának főbb tényezöit azonosították be, különös tekintettel a Budapest Spas termékcsaládra. $\mathrm{Az}$ egyéni kutatási interjúk az elméleti modell érvényességét vizsgálták, illetve a budapesti gyógyfürdők igénybevételének és a balneo kozmetikumok vásárlásának és fogyasztásának főbb változóit tárták fel, továbbá a rendelkezésre álló, tudatosan eltöltött szabadidőt, az egészségtudatosságot, a fizikai/mentális betegségek meglétét, a korábban igénybe vett gyógyfürdő szolgáltatásokat, és, hogy jelenleg vásárol/használ-e balneo kozmetikumokat a fogyasztó, és az ezek kombinációit bemutató vásárlási csoportosításirányok beazonosítását. Holisztikus megközelítésben a rekreáció, prevenció, regeneráció és a gyógyfürdő tevékenységekkel tudatosan eltöltött szabadidő kapcsolatot mutatnak egymással attól függően, hogy a fogyasztó milyen betegségekben szenved jelenleg, és ezekre alkalmaz-e különbözö balneo kozmetikumokat, de természetesen betegségek megléte nélkül is használnak a fogyasztók gyógyvíz alapú kozmetikumokat.

\section{A kutatás támogatói}

„Az Innovációs és Technológiai Minisztérium ÚNKP-20-3-II. kódszámú Új Nemzeti Kiválóság Programjának a Nemzeti Kutatási, Fejlesztési és Innovációs Alapból finanszírozott szakmai támogatásával készült.”

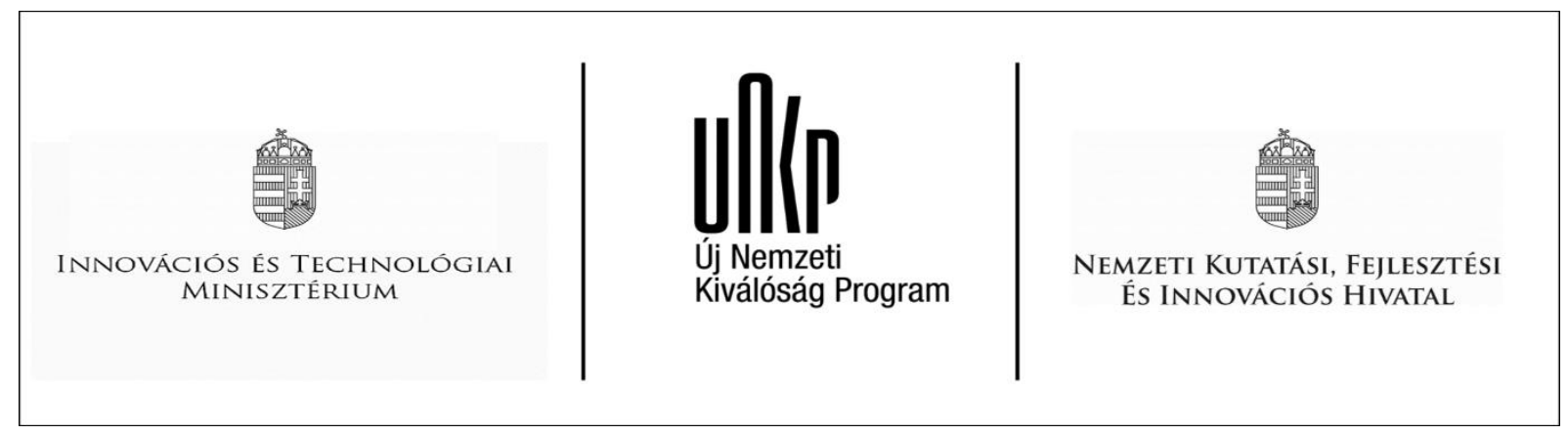




\section{Irodalomjegyzék}

Balneoportál (2018): Spatermékek készültek budapesti gyógyvizekből. http://balneoportal.hu/hirek/spatermekek-keszultek-budapesti-gyogyvizekbol. (lekérdezés ideje: 2020.06.02.)

Bauer A, Berács J. (1998): Marketing. AULA, Budapest. 620 p.

Bender T. (2008): Gyógyfürdözés és egyéb fizioterápiás gyógymódok. SpringMed, Budapest. 139 p.

Bircher, J., Hahn, E.G. (2016): Understanding the nature of health: New perspectives for medicine and public health. Improved wellbeing at lower costs. F1000Reserach. pp. 1-18. https://meikirchmodell.ch/wp-content/uploads/2016/11/2016-5-Understanding-the-nature-of-health.pdf.

Doi: 10.12688/f1000research.7849.1. (lekérdezés ideje: 2020.11.27.)

Brown, D.W., White, S. (2008): Alternatív gyógymódok. GABO, www.gabo.hu. 224 p.

Czető-Pauer K. (2013). Balneoterápia a gyógyvizekben. $\underline{\mathrm{https}: / / \text { spatrendonline.hu/spa- }}$ wellness/wellness/balneoterapia-a-gyogyvizekben. (lekérdezés ideje: 2020.06.02.)

Dembkowski, S. H., Lloyd, S. (2010): The environmental value-attitude-system model: A framework to guide the understanding or environmentally conscious consumer behaviour. Journal of Marketing Management, Volume 10, 7, pp. 593-603. DOI: 10.1080/0267257X.1994.9964307.

Engel, J. F., Kollat, D. T., Blackwell, R. D. (1973): Consumer Behaviour. Holt, Rinehart and Winston, New York. (lekérdezés ideje: 2020.08.05.)

Fási K. (2015): Szépségápolás otthon. Csengőkert. 127 p.

Fási K., Koronczai M. (1996): Házi kozmetika. Kossuth Könyvkiadó, Budapest. 184 p.

Heim P. (Szerk.) (2008): Wellness enciklopédia 1. EHCC, Tata. 200 p.

Ivens, S. (2018): Erdőterápia. Sinrin-joku, avagy zöld út a boldogsághoz. Libri, Budapest. 258 p.

Kertész E. (Szerk.) (2004): Spa-élmény Európában. A testi-lelki jólét leggazdagabb forrásai. Jószöveg Mühely, Budapest. 232 p.

Kiss B. (2018): Népegészségügyi fejlesztések Európai Uniós forrásokból. Miskolci egyetem. Egészségügyi Kar. Egészségügyi szervező alapszak. Egészségturizmus szervező szakirány.

Szakdolgozat. 82 p.

Kovács L. (Szerk.) (1985): Börápolás - szépségápolás. Kossuth Könyvkiadó, Budapest. 219 p.

Krémmánia (n.a.): https://kremmania.hu/. (lekérdezés ideje: 2021.02.15.)

Kunze, O.\&R. (1973): A szépség iskolája. Medicina, Budapest. 301 p.

Kurland (2020). Mit Der Kraft Der Natur: Mi az a spa? https://kurland.hu/blog/mi-az-a-spa. (lekérdezés ideje: 2020.10.15.)

Lehota J. (2001): Élelmiszer-gazdasági marketing. Müszaki Könyvkiadó, Budapest. 328 p.

Majláth M. (2009): A pszichográfiai tényezők különbségei a környezetbarát és nem környezetbarát fogyasztók között. PhD értekezés. Budapesti Corvinus Egyetem, Gazdálkodástudományi Kar. http://phd.lib.uni-corvinus.hu/420/. (lekérdezés ideje: 2021.01.11.)

Márk L. (Szerk.) (n.a.) A 29 legjobb szálloda és kozmetika itthonról és külföldröl. Budapest: k.n. In: László K. (szerk.) (n.a.): Otthoni Spa. In: Elle Hotel és Spa útikalauz. 38 p.

Notarnicola, I., Stievano, A., Pulimeno, A.M.L., Rocco, G. (2019): Systems Thinking, Complex Adaptive Systems and Health: An Overview on New Perspectives for Nursing Education. Book Methodologies and Intelligent Systems for Technology Enhanced Learning, 8th International Conference. Project: Systems thinking in nursing. pp. 1-13. (20) (PDF) Systems Thinking, Complex Adaptive Systems and Health: An Overview on New Perspectives for Nursing Education (researchgate.net). DOI: 10.1007/978-3-319-98872-6_34. (lekérdezés ideje: 2020.11.17.)

Romváry V., Gerő G. (1985): Modern test- és szépségápolás. Harmadik, átdolgozott és bővített kiadás. Natura-Medicina, Budapest. 394 p.

Shutt, K. (2002): Viz - a szépség és a jó közérzet forrása. Holló és Tsa, Kaposvár. 96 p.

Weiß, J. (2007): Szauna. Bocsoda, Debrecen. 79 p. 